\title{
Harmonization of Tradition and Religion in Ngukus Tradition in the Community of Ujungberung, Bandung
}

\author{
Zulkarnain Yani \\ \{yanizulkarnain77@gmail.com $\}$
}

Balai Penelitian dan Pengembangan Agama Jakarta

\begin{abstract}
Indonesia is a multicultural and multi-ethnic society that has rich traditions and rituals. The rituals contain meaning and cultural value as well as religion that become life guide among local communities. The diversity of culture, religion, and belief of Indonesian communities has coloured various traditions and rituals that exist in the country. Ngukusan tradition is an inherited custom from previous generations (adat karuhun urang) in Ujung Berung community, the city of Bandung. It is a burning of incense that is performed on certain days and for various socio-religious activities. This study focuses on what and how the ngukusan tradition is conducted, as well as on harmonisation between religion, culture, and a particular tradition. It is a qualitative descriptive method with an ethnographic approach in the form of a case study of the ngukusan tradition. Data were collected through participatory observation, interviews, and documentation. The results of this study show that there are combination and acculturation between Islam and local culture of the virtue ethics in the form of divine moral values and tolerance.
\end{abstract}

Keywords: Tradition, Culture, Ethical Values.

\section{INTRODUCTION}

Islam comes to the world as a mercy to the universe. As a religion that is full of mercy, its teaching can provide peace for the diversity of mankind on earth. In addition, Islam is known as a universal religion, where it respects the existence of customs, traditions, and cultures that already exist in society. For that reason, Islam as a religion can be well accepted among the community and not contradictory to what exist in them.

Likewise, the presence of Islam in Indonesia is the result of the dakwah or proselytizing process performed by the walis or saints and ulama through cultural approach that is in accordance with the local community. This is one of the reasons why Islam in Indonesia is able to develop and spread in a very short time. This is a sign that Islam is present in Indonesia as a flexible teaching and it respects the plurality that exists in society [1]. Therefore, the emergence and existence of local traditions and belief is inevitable.

However, the flexibility of Islam and its respect for local belief and culture has been overlooked by some groups of hardliners who bear the name of Islam. We still remember the event in October 2008 when the Banyuwangi regency held Gandrung Sewu festival that featured 1,300 dancers wearing regional traditional dance clothes. This is performed 
as a typical Banyuwangi welcome dance every time there is an activity or festival in Banyuwangi. The event of Gandrung Sewu dance was rejected by the Banyuwangi branch of Islamic Defenders Front (FPI) organisation which said that the Gandrung Sewu dance induced immortality that could bring punishment from God [2].

In the same month, precisely at Pantai Baru Ngentak, Poncosari, Srandakan, Bantul Special Region of Yogyakarta, the Larung laut event, which was supposed to be carried out by the local community, was cancelled. This was because the equipment for conducting the event of sedekah laut, offerings for the sea, were damaged by 50 (fifty) people on Friday night, 12 October 2018. Based on the narrative of the destroyers, that event was considered to have the elements of shirk, i.e. idolatry, polytheism or ascribing partners with Allah. They even unfurled banners at the venue that read, "We Reject All Culturally Wrapped Shirk/Kemusyrikan" [3].

A similar incident also occurred in Cilacap region on 12 October 2018 when the local community carried out the tradition of sea offerings or sedekah laut on Pantai Teluk Penyu - Cilacap. The sedekah laut event for the people of southern coast of Cilacap is a tradition that has been carried out from many generations before to the present generation. That event was once challenged by a group of people by unfurling provocative banners. However, this did not prevent the Cilacap residents from continuing the tradition of sedekah laut [4].

Certainly, the three events above are only a small part, if we trace it further, there will be found that various cultural tradition events have experienced rejection and even dismissed by groups of people or mass organisations acting on behalf of religion on the grounds that there are elements of bid'ah or heretic innovation, shirk and so on. As a nation that holds the slogan of Bhinneka Tunggal Ika, Unity in Diversity, that was a regrettable incident.

The concept of 'diverse yet one' has been uprooted because of the selfish attitude of a few people or those acting on behalf of religion who claim that their understanding and teaching are the most shar'i (correctly following the teaching of Islam), the most right and true according to the Quran and sunnah. Quite the opposite, in Islam, it is important to understand that 'urf, local tradition that is known to be good, in the form of saying or action can be part of Islamic teaching. 'Urf is also a custom or regional law that can go hand in hand with Islamic law [5].

In this context, this study on harmonisation between Sundanese culture and Islam in practice and ritual tradition of ngukusan in the community of Ujungberung district - the city of Bandung become very interesting to examine, in relation to the attitude of religious moderation in society. The tradition of ngukusan is one of the ancestral traditions of the Ujungberung community which has been carried out by many generations from the past to the present.

However, the socio-cultural changes that are taking place, as a result of modernisation, have significantly affected the local community, which has become increasingly 'pure' and santri, especially the immigrant community in the region. The contact between traditional communities and immigrants who carry the 'pure' teachings has made the tradition that has been running since the first generation of the Ujungberung community experience a process of decline.

This is indicated by the increasingly closed attitudes of the people who are still practicing these practices, which are seen as teachings and actions that contain shirk, bid'ah, and even deviance from the teaching of the Quran and the sunnah of the Prophet Muhammad. So, this research will provide information and answers on how the ngukusan 
tradition is still being carried out amid the swift process of 'puritanism' that occurs in Ujungberung community.

In addition, this research is inseparable part of the strategy of mainstreaming the religious moderation through studies of existing traditions and culture in society. Religious moderation itself is a religious attitude that is balanced between the practice of one's own religion (exclusive) and respect for the religious practices of other people with different belief (inclusive). Religious moderation in the context of Indonesian society is not an option, but is a necessity amidst the diversity and differences that exist so as to create a life of peace and harmony[6].

Based on the discussion above, there are several main research questions that are the focus of this research; first how has the concept of ngukusan been forming in the context of the tradition of the Ujungberung people, past and present? second how does the meeting between the ngukusan tradition and religion happen? third what ethical virtues conveyed in the ngukusan tradition?

This study aims to provide an overview of the harmonisation between the cultural tradition of ngukusan that exist in Ujungberung community - the city of Bandung with the teachings of Islam in a cultural context. The significance of this research is the result that show the overviewo of the harmonisation of culture and religion in the ngukus tradition with various perspectives.

Based on literature study, we haven't found any research that examines the tradition of ngukus specifically. Ramdan [7] in his writing on "Membangun Citra Reak Sebagai Media Komunikasi Budaya dan pendidikan", 'Building a Reak Image as a Media for Cultural Communication and Education' states that ngukus is part of the ceremony before the reak show which is only a series of thanksgiving to Allah.

Umam et al [8] wrote an article "Pesan Dakwah pada Upacara Adat Ngeuyeuk Seureuh", 'Dakwah Message at the Nheuyeuk Seureuh Traditional Ceremony' in which it discusses ngukus is one of the rituals performed before the marriage takes place with some equipment, including incense, young coconut, some fruit salad 'rujak', and so on. These offerings were given a $d u$ ' $a$ or jampe (mantra) by ancestors or community leaders there with a specific purpose.

There are several studies and writings that can strengthen research from aspect of material enrichment regarding Sundanese culture. Miharja [9] writes on "Sistem Kepercayaan Awal Masyarakat Sunda", 'The Sundanese Early Belief System' where he explained that the Sundanese people have a very unique belief system which is reflected in the Sundanese Wiwitan religion. The Sundanese Wiwitan belief system has a monotheistic belief concept, worshiping only one God, which is called Sang Hyang Kersa. The Sundanese Wiwitan belief actually influences the concept of life of the Sundanese people, the Tritangtu in everyday life.

Sumardjo [10] wrote about "Kosmologi dan Pola Tiga Sunda", 'Cosmology and the Three Sundanese Pattern' where he explained that the pattern of 'triple unity' in Sundanese Wiwitan society is still alive with different concepts. The triple relationship pattern is a practice of how humans work in realising objects need in life. Sundanese identity is not just objects, but Sundanese way of working or Sundanese way of thinking in producing cultural objects.

\section{RESEARCH METHOD}

This research was conducted in Ujungberung subdistrict-Bandung city. The 
exploratory study was carried on 26 to 30 September 2019 and data collection was conducted on 10 to 17 October 2019. This research uses a qualitative-descriptive method with an ethnographic approach in the form of a case study of the ngukusan in Ujungberung community in Bandung. Data were collected through; 1) direct observation on how the tradition was held by the people who perform the ngukusan tradtiion, 2) documentation or recording of how the process of ngukus tradition was carried out by the community in Ujungberung. This is intended to obtain a complete picture of the process of ngukusan from the beginning to the end. The recording was done when the ngukusan tradition was performed by Abah Dayat at the tomb on Monday night at 20.00 until it finished, and 3), interviews were also conducted with several sources (community and religious leaders) who disagreed (contra) with the ngukus tradition and who agreed with it. This method was used to obtain a description and reasons why the ngukusan tradition is accepted and not accepted by the community or religious figures.

At the data processing stage, we used data reduction method. This method is used to select and sort data from interviews with various sources, so that the interview data that are not related to the research would be put aside first before they are compared with the data that are directly related to the research focus. In analysing the text, we used structural and functional methods. Traditions and culture that exist in society generally have their respective functions. Likewise, the ngukusan tradition has a function in socioreligious life. The structural method was used to determine in detail the materials used at the time when ngukusan and its procession were conducted

\section{RESEARCH RESULT}

This part will discuss the data obtained from the field. The discussion is divided into several parts; first about the variety of Sundanese traditions in the Ujungberung region, what is and how ngukusan is practiced in the region, including about the tradition actors, procession, motivation, and substance. Second, about the identity of "Abangan" in Tatar Sunda; about practice and motivation of the ngukusan tradition and third is about virtue ethic that can be taken from the ngukusan tradition.

\section{Varieties of Sundanese Traditions in the Ujungberung Region - Bandung}

There are several Sundanese traditions and culture that are still being carried out and preserved by the people of Ujungberung. The Sundanese traditions and culture include; ngabungbang (bathing in seven springs on the night of the $14^{\text {th }}$ month of Maulid), bancakan (the tradition of eating together with nasi tumpeng in a large field as a means of tolak bala or preventing disaster from happening or when there is someone who has illness, led by the community's revered elders), ngukusan (burning incense every Tuesday night and Thursday night, this tradition is also carried out at several socio-religious events), ngameli (harvesting tradition accompanied by the arts of terbangan and benjang), mepende (putting children to sleep), benjang martial arts, reak, puput puser, nyusur tanah and other various traditions and cultures ${ }^{1}$.

${ }^{1}$ The information and date were processed from several informants, among others: $\mathrm{H}$. Hoeruman (Ketua MUI Kec. Ujungberung also the head of Tanfidzhiyah MWC NU Ujungberung) and Gugum Gunawan. 


\section{What is and How Ngukusan is Conducted}

Ngukus comes from the word "kukus" which means "mengepul", smoking, "berasap", steaming, or "mengeluarkan asap", emitting smoke. In Sundanese culture, ngukus is a derivative activity of burning incense in a certain ritual [11]. Frankincense is an object that emits a fragrance when it is burned, which aims to make people at the event feel comfortable. People in Indonesia, when they hear the phrase "Frankincense", what is in their minds is something that is closely related to things that are mystical, shirk, and only done by a dukun or a shaman.

Frankincense is used for certain events, such as weddings, religious assembly or majelis ta'lim, tasyakuran, selametan (such as for tasyakuran - thanksgiving), places of pilgrimage (like tombs of saints, 'wali') and so on. At the Nabawi Mosque or Masjid al-Haram, incense is often present at several events such as the Tahfidh Graduation ceremony, the purification or cleaning of Ka'bah ceremony, and so on. It is to scent the air and delight the soul of the pilgrims or visitors. One of the reasons they did this thing is based on a narrated hadith of the Prophet Muhammad, that the angels love fragrant smells and hate bad smells. In Sundanese society, ownership of incense can indicate the level of social status of the owner, if the incense is high quality, then he is a rich person, and vice versa [12].

The identity of 'Abangan' in Tatar Sunda; Practices and Motivations for the Ngukusan Tradition in Ujungberung - Bandung.

The tradition of ngukusan is still carried out in 3 (three) out of 5 (five) sub-district or kelurahan in Ujungberung district. The 3 (three) kelurahans are Pasir Wangi, Pasir Jati and Pasir Endah. Meanwhile, in the other two 2 (two) kelurahans, Cigending and Pasanggrahan, the ngukusan tradition is no longer practiced.

In Cigending subdistrict, based on Abah Entis' information [13], since the 1980s, the people in Cigending have no longer practiced the ngukusan tradition. The tradition has been lost after the entry of preachers from other areas to Cigending delivering religious sermon and study, pengajian, criticising that sending prayers to people who have died does not need to use the means of ngukus, 'it is enough to just pray', they said. However, there are things that are contrary to his statement later, at the $17^{\text {th }}$ of August 2019 independence celebration, in welcoming guests from the subdistrict and district authorities, Abah Entis did ngukus before the procession began. This is certainly an interesting phenomenon, at the place where the ngukusan tradition is no longer practiced, said Abah Entis, in fact it was held to welcome the guests in the event of $17^{\text {th }}$ of August Indonesian independence ceremony. In Harum Sari village or kampung, according to the information from Pak Asep, a religious counsellor in Cigending, there is one resident, Pak Arum, who is still practicing the ngukusan tradition. However, when we met Pak Arum and talked directly to him, he seemed to cover up the matter. Perhaps this is due to the view of the surrounding community that carrying out this tradition is an act of shirk, deviant from religious teaching of Islam.

We also interviewed two people in Cigending, Pak Yayat (67 years old) and Pak Lukman (40 years old) [14]. According to Pak Yayat, this tradition was once carried out by his greatgrandfather and grandfather, and even his father had been practicing it but not for long. The tradition is no longer practiced in Pak Yayat's family because he gets information from religious lectures delivered by immigrants to Cigending (from Ciamis, Garut who are from the organisation of Muhammadiyah and Persis) that the tradition does not exist in Islamic teachings. When Pak Yayat's grandfather passed away, they performed ngukusan. The same thing was also conveyed by Pak Lukman, that since 2002, the tradition of ngukusan in his 
family had no longer been carried out, with the same cause as said by Pak Yayat before.

Similarly, in Pasanggrahan subdistrict, according to Abah Rahwan [15], people in Pasanggrahan have no longer practiced the tradition since long time ago in the 1980s. According to him, the Pasanggrahan community no longer practice this tradition because of the presence of preachers who come to Pasanggrahan and deliver their sermon claiming that there is no such tradition in Islamic teachings. In fact, in Pasanggrahan, according to the information obtained from the religious counsellor in Pasanggrahan, there are residents who still practice the traditions of their ancestors, but it is done secretly, like in Neglasari and other regions. This is understandable, because Pasanggarahan area, according to the information obtained, is the base for one of the political parties (Justice and Prosperous Party - PKS whose members are often seen as conservative Muslims), so that various Sundanese traditions have completely gone.

As explained above, this ngukusan tradition is still practiced in 3 (three) other subdistricts (kelurahan); Pasir Wangi, Pasir Endah and Pasir Jati. In each of this subdistrict, there are main actors who carry out the tradition. In Pasir Wangi, there is Abah Ading, Kang Gugum and about 12 other people who still practice the tradition. In Pasir Jati, the main actor of the tradition is Abah Dayat Hidayat in Pasir Kunci.

One of the important elements in a tradition is ritual. Ritual is an adjective of rite and is also a noun. As an adjective, ritual is anything that is connected or associated with religious ceremonies, such as ritual dance and ritual law. Meanwhile, as a noun, it is anything that has religious ceremony characteristic [16]. Ngukusan tradition is carried out every Tuesday night and Thursday night before maghrib prayer. Usually it is held at one of the places in the house. On Sunday night, the ngukusan ritual is carried out at the sacred tomb of puyang or their ancestors [17].

The first procession is carried out just before maghrib prayer by burning incense at the beginning. After the maghrib prayer, the procession continues with a ritual initiated by reciting the ta'awudz اعوذ باله من الشيطان الرجيم followed by بسم الله الرحمن الرحيم and saying the shahadah (testimony of faith), istighfar (asking for forgiveness from God) phrase, and reciting al-fatihah sent or presented to the Prophet Muhammad and his companions, and the ancestors (Puyang)

Before it is finally ended by reciting the supplication or $d u^{\prime} a$. The ngukus tradition is generally carried out to initiate prayers and rites at certain moments, apart from being performed on every Sunday, Tuesday, and Thursday night, as well as for socio-religious events. These moments include the shukuran or slametan, a kind of thanksgiving after getting fortune, at the time of harvesting rice, death, building a house, tomb visit, and burying the baby's placenta [18].

The equipment used when performing the ngukus tradition are;

1. Frankincense

2. Charcoal

3. Incense

4. Cigarettes

Based on the results of observation that lasted about 7 (seven) days at the research location, we got an idea that the actors of ngukusan tradition in Ujungberung area could be categorised as "Abangan Sunda". Geertz (1964) [19], in his study, classified the Javanese people (especially in the region of Pare - Kediri, Jawa Timur) into 3 (three) groups; abangan,

${ }^{2}$ We haven't found the right term or category for the case in Ujungberung. So we try to borrow the term "Abangan" Geertz by seeing the characteristics explained by Geertz. 
priyayi and santri. The division of the 3 (three) groups of people is based on their view of life. Abangan, according to Geertz, is a group of people who colour their lives with various ceremonies of slametan, traditional medicine practices, and belief in spirits and supernatural powers. The santris are identified with adherence to the teachings of the Islamic religion and involvement in various social and political organizations that bear the name of Islam. Meanwhile, the priyayis are identified with the white-collar elite which is part of the government bureaucracy.

The question is then whether the people who still practice the ngukusan tradition in Ujungberung can be categorized as "Abangan Sunda". Based on the results of observation, the actors of the ngukusan tradition are middle to lower income people who work as tukang ojek (motorcycle taxi drivers) and farmers in the rice fields. It is difficult to find the actors from the upper middle-income community. Apart from the economy, the actors of the ngukusan tradition are people who still adhere to various traditions and ancestral cultures, buhun, the legacy of their ancestors. The various existing socio-religious activities are still very identical to the old traditions such as bancakan, ngameli, nyusur tanah, ngukusan and ngabungbang. The relationship between religion and tradition in Sundanese society is very difficult to separate because these traditions function to regulate the attitudes and value systems of life. Traditions are still carried out as long as they do not conflict with existing religious teachings.

In essence, religious teachings command good and prohibit evil. Therefore, a practice that is wrongly done will bring harm but a practice that is true according to the sharia will result in happiness and salvation. According to Abah Dayat and Kang Gugum [20], the motivation in carrying out the ngukusan tradition, apart from preserving the traditions of the ancestor, is a belief that it can control human desire where the embers of fire (red fire) serve as a reminder that every human being can avoid hellfire with patience, not by anger, when he or she was struck by disaster. In addition, this tradition serves as a reminder of all mistakes that have been done, in the hope that the mistakes that have been made will not be repeated in the future.

However, the ngukusan tradition turned out to be rejected by the religious 'purification' movement that come from outside Ujungberung who preached their conservative approach against the tradition. Based on the results of interview with the community, the ngukusan tradition was rejected by the $d a{ }^{\prime} i$ (proselytizer) who come from outside the area to preach in Ujungberung. Through various religious assembly 'pengajian', the preachers claimed that the ngukusan tradition does not exist and is against the teachings and sharia of Islam. So, those who still practice this tradition are among the polytheists because they put their hope to something other than Allah.

The same thing was also stated by Dr. Zam Zam [21] and Ustadz Cepi [22], that ngukusan tradition does not exist at all in the Quran and Sunnah (Prophet Muhammad's tradition). They, therefore, asserted that the tradition is an act of shirk because people ask for something through the ancestors, not to Allah. This kind of act is known among them as abbreviated TBS "takhayul, bid'ah and khurafat. Even these conservative religious figures call the people who practice the tradition as "Islam keturunan", who do not have knowledge of Islamic teachings and are wasteful because they buy incense and burn it for ngukus.

\section{The Ngukusan Tradition as a Media for Cultivating Virtue Ethic in the Community}

Virtue Ethic is an ethic that studies virtue, the main character possessed by humans. Ethic of virtue is a variant of theory in the branch of normative ethics which focuses more on moral issues. This ethics describes a person's achievement to the level of goodness and certain personal qualities. Thus, the main requirement of this virtue ethic is to be a good human being, 
a complete human being, a human being who has the main personality, behaviour, and ethics. This virtue ethic leads to the development of a good human personality to be continuously consistent in behaving and acting virtuously for the surroundings [23]. In the context of this research, virtue ethics that can be taken from the tradition is moral ethics and tolerance.

Moral is one of the products of culture and religion which regulates the way of interaction (actions, behaviour, and speech) between humans. In other words, the term moral refers to the actions, behaviour of someone who has positive values according the norms that exist in a society. Moral is also one of the basic attitudes that a person must have in order to be a good and right person, both in behaving well with God the Creator, family, and society.

The tradition of ngukusan, based on the observation conducted in the field, give birth to human individuals who have morals in their daily lives. The moral values that can be learned are divine morals and tolerance. The actors of the ngukusan tradition are Muslims who are obedient in carrying out the Islamic teachings in their daily lives. Mutual respect for fellow humans and respect for fellow believers or followers of different religions is a manifestation of the divine morality that these actors practice in society.

In fact, even though this ngukusan tradition is opposed by a group of people of the same Islamic faith, the actors of the tradition have never put up a fight and question the presence of these conservative 'puritan' movements which are increasingly mushrooming, and which have resulted in disappearance of this old and long-lasting tradition. The actors of the tradition can live in harmony with other groups who have different understandings in religious teachings. The response of the actors towards the opponent of the tradition shows tolerance, which is the spirit of the actors in social-community life. They can accept and understand that there are differences in religious understanding, which has led to different ways of worship, where in their case is based on local traditions and culture.

\section{CONCLUSION}

Based on the results and discussion, there are several conclusions that can be drawn. First, the concept of ngukusan tradition in the context of the past and present Ujungberung community is not much different. Every Tuesday night and Thursday night before maghrib prayer, the ngukusan is carried out at a place in the house. On Sunday night, it is conducted at the sacred tomb of the puyang, their ancestors. In their practice, the actors of ngukusan carried out the tradition openly before the 1980 s but began to hold it secretly nowadays because of the opponent understanding against the tradition, which is promoted by the conservative preachers who come to and live in Ujungberung. These preachers spread their message through religious assembly, pengajian, claiming that the tradition is bid'ah, heretic innovation, and is shirk, deviant from the teachings of Islam. In fact, this assumption is not true because the opponent group have not understood the meaning of the tradition and they have not even observed or participated directly in the tradition.

Second, we can see the meeting between the ngukusan tradition and religious teachings at the time when the activities of the tradition are taking place. The ritual is begun with reciting

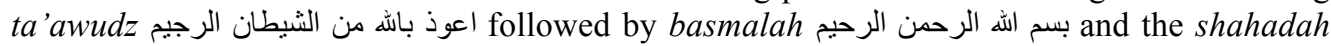
(testimony of faith), istighfar (asking forgiveness from God) and al-fatihah delivered to the Prophet Muhammad and his companions, and the puyang, the ancestors, and it is ended by reciting the $d u^{\prime} a$ (supplication). Finally, the tradition brings forth a virtue ethic in the form of divine moral ethics and tolerance, where the actors of the tradition, while still carrying out the tradition of their ancestral heritage, are Muslims who are obedient in carrying out the 
teachings of Islamic religion in their daily lives. It is shown by the way they respect the difference in understanding religion, as an implementation of divine moral ethics and tolerance in social-community life

\section{REFERENCE}

[1] Sumpena, Deden., 2012. "Islam dan Budaya Lokal: Kajian terhadap Interelasi Islam dan Budaya Sunda", Jurnal Ilmu Dakwah; Academic Journal for Homiletic Studies, Vol. 6 No. 1 Juni 2012. 107. DOI : $10.15575 /$ idajhs.v6i1.329

[2] Fanani, Ardani., 2018. "Ditolak Ormas Islam, Festival Gandrung Sewu 2018 Tetap Digelar".https://news.detik.com/berita-jawa-timur/d-4262361/ditolak-ormas-islamfestival-gandrung-sewu-2018-tetap-digelar. Accessed on Wednesday, $18^{\text {th }} 2019$.

[3] Pertana, Pradito Dita., 2018. "Tradisi Sedekah Laut Ditentang, Banyak Kalangan Meradang”. https://news.detik.com/berita-jawa-tengah/d-4255648/tradisi-sedekah-lautditentang-banyak-kalangan-meradang. Accessed on Wednesday, $18^{\text {th }} 2019$.

[4] Muzakki, Khairul., 2018. "Sempat heboh karena spanduk sedekah laut di pantai Selatan Cilacap berlangsung meriah". https://jateng.tribunnews.com/2018/10/12/sempat-hebohkarena-spanduk-sedekah-laut-di-pantai-selatan-cilacap-berlangsung-meriah. Accessed on Wednesday, $18^{\text {th }} 2019$.

[5] Khallaf, 'Abdul Wahhab., 1968. 'Ilmu Ushul Fiqh. Mesir: Dar al-Kuwaytitah, 89, and Cryril Glasse., 2002. Ensiklopedi Islam. Transleted by Ghufron A. Mas'adi. Jakarta: RajaGrafindo Persada.. 421.

[6] Authors Ministry of Religious Affairs of Indonesia Republic, 2019. Moderasi Beragama. Jakarta: Badan Litbang dan Diklat Kementerian Agama RI. 18.

[7] Ramdan, Ahmad Taufik Maulana., 2017. "Membangun Citra Reak Sebagai Media Komunikasi Budaya dan pendidikan", in Book Chapter Public Relations and Tourism. Susanne Dida dkk (ed). Bandung: Unpad Press. 36

[8] Umam dkk, Zazam Khairul., 2017. "Pesan Dakwah pada Upacara Adat Ngeuyeuk Seureuh". Jurnal Tabligh. Volume. 2 Nomor. 1. 121. DOI: 10.15575/TABLIGH.V2I1.34

[9] Miharja, Deni., 2015. "Sistem Kepercayaan Masyarakat Sunda". Jurnal Al-AdYaN. Vol.X. N0.1. Januari-Juni.

[10] Sumardjo, Jakob., 2009. "Kosmologi dan Pola Tiga Sunda”. Jurnal Imaji. Vol. 4. No. 2. Februari.

[11] Rusmana, Dadan., 2011. "Ngukus: Tradisi Membakar Kemenyan", https://dadanrusmana.wordpress.com/2011/04/21/ngukus-tradisi-membakar-kemenyan/, Accessed on September $2^{\text {nd }}, 2019$.

[12] Samantho, Ahmad Yanuana., 2016. "Manfaat Kemenyan dari Sudut Pandang Islam", https://ahmadsamantho.wordpress.com/2016/07/18/manfaat-kemenyan-dari-sudutpandang-islam/. Accessed on September $3^{\text {rd }}, 2019$ and Mohammad Fathi Royyani, 2018. "Islam dan Kemenyan: Wangi yang Abadi", https://alif.id/read/mohammad-fathiroyyani/islam-dan-kemenyan-wangi-yang-abadi-b213529p/. Accessed on September $3^{\text {rd, }}$ 2019

[13] Interview was conducted on Tuesday, 15 Oktober 2019, Abah Entis is 62 years old and is a revered elder and the head of RW in Kampung Harum Sari - Cigending

[14] Interview was conducted on Monday, 14 October 2019

[15] Interview was conducted on Thursday, 11 October 2019 at the residence of Abah Rahwan 
in kampung Maruyung Pasanggrahan

[16] Agus, Burtanuddin., 2007. Agama dalam Kehidupan Manusia: Pengantar Antropologi Agama. Jakarta: PT. Raja Grafindo Persada. 96.

[17] Interview with Abah Dayat, on October 11, 2019

[18] Processed from several informants in the field (Abah Entis, Abah Dayat, Kang Gugum and Pak Chaeruman)

[19] Santosa, Agus., 2010. "Geertz: Abangan, Priyayi dan Santri", https://agsasman3yk.wordpress.com/2010/01/30/geertz-abangan-priayi-dan-santri/. Accessed on September $4^{\text {th }}, 2019$.

[20] Interview on Sunday, 13 October 2019 at the residence of Abah Dayat and residence of Kang Gugum on Thursday, October 10.

[21] He is the head of PC Muhammadiyah Ujungberung and lecturer at UIN Sunan Gunung Djati Bandung

[22] He is a Muballigh, preacher of Persis in education division in area of Ujungberung

[23] M. Nur Prabowo Setya, "Etika Keutamaan (Virtue Ethic); Sebagai Dasar Filosofis Bagi Pengembangan dan Pembangunan Karakter Manusia", https://www.academia.edu/31042673/ETIKA KEUTAMAAN VIRTUE ETHICS SEBA GAI DASAR FILOSOFIS BAGI PENGEMBANGAN DAN PEMBANGUNAN KAR AKTER MANUSIA. Accessed on Oktober $4^{\text {th }}, 2019$. 